\title{
THE INFLUENCE OF CATTLE ON PASTURE COMPOSITION AND SECOND GROWTH CONTROL
}

E. A. MADDEN, Farm Advisory Officer (Agrostology), Department of Agriculture, Palmerston North.

The observations, over some years, relate to two steep hill country stations where cultivation could not be undertaken and no topdressing had been done.

By reducing sheep and increasing cattle, beneficial changes in pasture composition were achieved. In one case cattle were rotationally grazed; in the other they were set stocked.

One property is on the East Coast toward Cape Runaway and is bounded by the sea on one side; the hills rise to about 1,000 ft. The other station is inland toward Raetihi and lies between 1,500 and $2,500 \mathrm{ft}$; the hills are very steep and valleys very narrow.

Climatic conditions at the two places are quite different. Mild and fairly equable conditions prevail on the coastal station and there is only a short period of winter dormancy. Cold winters and a longer period of winter dormancy are characteristic of the inland station. Both places have a fairly well distributed rainfall of over 60 in.; short summer droughts occur.

\section{Pastures}

After the various bush burns the country was sown with seed mixtures typical of those used at the time (20 to 40 years ago). For the first two to four years ryegrass, cocksfoot, crested dogstail, and white clover were the dominant species. As in most hill country, there was a steady decline in soil fertility and the pastures deteriorated in quality and productivity. As the sward weakened, sheet erosion took its toll of surface soil and animal manures, thus causing a further decline in fertility. Slowly the open pastures were invaded by fern, scrub, bidibidi, inferior grasses, and weeds. Scrub cutting and burning off were recurring jobs.

Grasses sown on secondary burns failed to survive any longer than on primary burns. They were slowly replaced by danthonia, sweet-vernal, browntop, Yorkshire fog, hairgrass, and a few small annual clovers. Moss and a wide variety of pasture weeds established freely.

On the East Coast property any poor or dry places were invaded also by ratstail, ricegrass, and lovegrass. On this station, subterranean clover, Lotus major, and paspalum were included in secondary burn mixtures. Prolonged wetness of the soil and hard 
grazing by sheep restricted the growth and spread of subterranean clover. Paspalum established and spread slowly, but was not very productive. Lotus major established slowly, but subsequently became widespread in pastures and among hard fern, rushes, sedges, bracken, and scrub.

About 20 years ago both farmers decided to modify their grazing management. They realised that the most palatable and nutritious grasses were being weakened by continuous grazing by sheep, that less palatable species and weeds were gaining ground, and that bidibidi, hard-fern, and manuka established and spread freely in close-grazed, open pastures. On the East Coast tauhinu was nearly as aggressive and troublesome as manuka.

As a result of experience and through a determination to hold his country if at all possible, each farmer resolved to reduce his sheep by about 25 per cent in a relatively short time. When extra feed became available through more lenient grazing the number of cattle was increased,

\section{Cattle Grazing and Management}

Because some of the hills on the East Coast station were not dangerously steep, it was possible to run a number of breeding cows. Here cattle were rotationally grazed according to the needs of stock and pastures. In some years cattle losses were serious, but over about 15 years the number of cattle rose from less than 300 to over 800 of all ages. All were bred on the farm. As pastures improved so did the cattlc, and losses were reduced substantially.

The hills on the inland station were far too steep for breedingcows. The farmer's experience was that to move cattle from paddock to paddock caused heavy losses, so set stocking was adhered to. All cattle were bought in at from 18 months upward and the number rose gradually from about 400 to 1,750. Mature fat cattle were sold and immediately replaced with young stock; hence cattle of all ages were in each and every paddock. As they got to know their home paddock very well, losses were reduced.

Cattle lived mainly on the lower slopes while feed was plentiful. After a large mob of sheep had been in the paddock for a few days the cattle were forced to work higher and still higher up the hills. Sheep were not rotationally grazed in the strict sense; it was a combination of rotational grazing and set stocking according to seasonal work, farm activities, and the farmer's judgment. As a rule, the sheep were in three or more mobs. By the grazing management adopted, the pastures were closely grazed at long intervals, but only for a relatively short time on each occasion. Thus selective grazing, which is detrimental to a sward, was minimised. 
Because water was available in the valley bottoms only, cattle had to tramp the slopes frequently. This resulted in severe damage to bidibidi, hard-fern, second growth, and many weeds.

\section{Sheep Health and Wool Production}

Through modified management, the type and quality of sheep feed was more uniform, the wool was cleaner, in better condition, and of better quality. For a time, wool production was lower but through an increase in fleece weight the total amount of wool sold compared favourably with that of former years. Higher lambing percentages were attained on both stations. Sheep drenching was never necessary on the inland station and on the coastal one it was reduced to a fraction of what it had been formerly.

\section{Changes in Pasture Composition}

Provision of sufficient cattle feed required that the pastures should carry a fair length of leafage most of the year. Except for short periods, there was no selective grazing, so no particular plant was kept short continuously. By having extra leafage for long periods the grasses developed strong root systems and individual plants grew more vigorously. Consequently vestiges of ryegrass, cocksfoot, crested dogstail, Poa pratensis, Yorkshire fog, and clovers took a new lease of life, became conspicuous in the sward, and ultimately were the dominant species on most of the hills.

Through lenient grazing on the East Coast station subterranean clover re-seeded from the few remaining plants and spread, especially on the drier faces. Lotus major spread slowly and almost inconspicuously until given an opportunity to assert itself under cattle grazing. Subsequently it produced well, especially in shady and damp situations. A similar sequence of events occurred with white and annual clovers. On lower slopes and in richer and moister places Poa trivialis became a useful feed producer, while tall fescue was suppressed and less aggressive. As soil fertility was raised by clovers, ratstail plants became weaker and sparser.

Under sheep grazing paspalum was stunted and almost valueless, but in later years it became relatively productive. Although danthonia still persisted on hard, dry situations, its growth and palatability improved as clovers spread through it.

Much the same story applies on the inland station; inferior and low-producing plants have been replaced very substantially by ryegrass, crested dogstail, white clover, Yorkshire fog, and suckling clover, while browntop, which was one time stunted and low-producing, became a fairly high-producing, palatable grass. 
The sequence over three or four decades was from a dominance of good species to a dominance of low producing ones and then back to the former.

Through increasing cattle, other changes, equally as important on hill country, occurred. Bracken was chewed and crushed out and by a combination of smother and tramping, bidibidi and hardfern were almost eradicated. In the taller and denser pastures, germination of manuka seeds was almost inhibited and many seedlings which appeared were inadvertently eaten or tramped and killed.

On the East Coast station, tauhinu continued to spread (and was almost as obnoxious as manuka) under close grazing, but after sward improvement tauhinu is no longer such a menace.

For several years the two properties referred to contrasted markedly with neighbouring ones where hard fern, manuka, and bidibidi were gaining ground in the ever-weakening pastures. Changes in ownership altered this; some neighbouring places have been improved and others have been abandoned to second growth.

During the early period that pasture changes were observed on these two properties there was no such thing as aerial topdressing. When it did become possible it was regarded as a doubtful economic venture, firstly because freight and haulage costs on fertiliser over long distances were high and secondly because the flying distance from the nearest airstrip made spreading charges almost prohibitive. However, the pastures are now composed of responsive species and when topdressing costs are within the reach of the respective owners they will, no doubt, take the opportunity of raising the productivity of their farms still higher.

I regard pasture management as perhaps the most powerful of all factors in making or spoiling pastures and I trust my contentions are adequately supported by the evidence presented.

Large tracts of hill country are still carrying poor, lowproducing pastures and there are vast areas of steep land still to be grassed.

From past experience it is obvious that, where possible, soil fertility must be maintained, or even raised, right from the start. Some properties are so remote from rail, ports, or airfields that topdressing may be too expensive in the initial development or improvement stages.

From an economic angle, whether for the individual farmer or for the nation, proper pasture management should far surpass the haphazard topdressing that has been carried out in some places. Unquestionably, good management in conjunction with discriminate topdressing, will turn steep hill country into a permanent national asset. 


\section{BOTANICAL NAMES OF SPECIES MENTIONED IN TEXT}

$\begin{array}{ll}\text { Annual clovers } & \text { Trifolium dubium; } \text {. striatum; T. } \\ \text { Bidibidi } & \text { Acaena sanguisorbat } \\ \text { Bracken } & \text { Pteridium spp. } \\ \text { Browntop } & \text { Agrostis tenuts } \\ \text { Cocksfoot } & \text { Cyctylis glomerata } \\ \text { Crested dogstail } & \text { D.pilosa and D. semiannularis } \\ \text { Danthonia } & \text { Vulpia myuros } \\ \text { Hairgrass } & \text { A ira caryophyllea } \\ & \text { Paesia scaberula } \\ \text { Hard-fern } & \text { Eragrostis elongata } \\ \text { Lovegrass } & \text { Leptospernum scoparium } \\ \text { Manuka } & \text { Paspalum dilatatum } \\ \text { Paspalum } & \text { Sporobolus capensis } \\ \text { Ratstail } & \text { Microlaena stipoitles } \\ \text { Ricegrass } & \text { Lolium perenne } \\ \text { Ryegrass } & \text { Jutus spp. } \\ \text { Rushes } & \text { Carex spp. } \\ \text { Sedges } & \text { Trifolium subterraneum } \\ \text { Subterranean clover } & \text { Anthoxanthum odoratum } \\ \text { Sweet-vernal } & \text { Festuca arundinacea } \\ \text { Tall fescue } & \text { Cassinia leptophylla } \\ \text { Tauhinu } & \text { Trifolium repens } \\ \text { White clover } & \text { Holcus lanatus } \\ \text { Yorkshire fog } & \end{array}$

